\title{
Perspectivas quanto à lavagem de provas na colaboração premiada: proposta para controle de abuso processual
}

\author{
Perspectives on evidence laundering in awarded collaboration \\ agreements: a proposal on controlling prosecutorial malfeasance
}

\author{
Guilherme Brenner Lucchesi ${ }^{1}$ \\ Universidade Federal do Paraná - Curitiba/Paraná, Brasil \\ guilherme@lucchesi.adv.br \\ http://lattes.cnpq.br/1512135510310992 \\ Dttp://orcid.org/0000-0001-9505-421X
}

\begin{abstract}
Lucas Gandolfi Vida ${ }^{2}$
Escola da Magistratura Federal do Paraná - Curitiba/Paraná, Brasil lucasgandolfi2375@gmail.com

http://lattes.cnpq.br/7877504826684459

http://orcid.org/0000-0002-7119-5736
\end{abstract}

\begin{abstract}
Resumo: Identifica-se no processo penal a possibilidade de dissimulação ou ocultação da origem de uma informação inutilizável no processo como fonte de prova, a fim de conferir aparência de legitimidade à sua origem, especialmente em acordos de colaboração premiada. Este fenômeno é denominado pelos autores "lavagem de provas", tratando-se
\end{abstract}

1 Doutor em Direito pela Universidade Federal do Paraná (UFPR). Doutor em Direito pela UFPR. Master of Laws (LL.M.) pela Cornell Law School (EUA). Professor de Direito Processual Penal da Faculdade de Direito da UFPR. Vice-coordenador do Curso de Direito da UFPR. Professor Permanente do Programa de Pós-graduação em Direito da UFPR (Capes 6). Diretor Financeiro do Instituto dos Advogados do Paraná (IAP), Gestão 2021/2023. Advogado criminal. Inscrito na Ordem dos Advogados do Estado de Nova York, Estados Unidos da América (NYSB).

2 Pós-graduando em Direito Público e Direito Contemporâneo pela Escola da Magistratura Federal do Paraná. Graduado em Direito pelo Centro Universitário UniCuritiba. Pincadista da $40^{\mathrm{a}}$ Edição do Programa de Intercâmbio do CADE. 
de situação processual ainda pouco discutida academicamente. Para análise deste fenômeno, este trabalho inicia pelo exame da natureza jurídica da colaboração premiada, bem como pelas etapas de seu procedimento. Busca-se, pela análise da lavagem de provas a partir da necessidade de preservação da cadeia de custódia de provas, identificar as consequências jurídicas deste fenômeno. A partir da experiência do programa de leniência do CADE, são propostas possíveis medidas para o controle do abuso processual pela acusação. Conclui-se que a instituição de uma central única para colaborações premiadas, com o fim de melhor gerir a prova advinda de acordos desta natureza, aliada à difusão de boas práticas na negociação de acordos, pode trazer maior segurança jurídica aos pretensos colaboradores, de modo a evitar a lavagem de provas.

Palavras-Chave: Lavagem de provas; Colaboração premiada; Abuso processual.

ABSTRACT: This article identifies a possibility of dissimulation or concealment of the origin of unusable information in criminal proceedings as a source of evidence, in order to give an appearance of legitimacy to its origin, especially in awarded collaboration agreements. This phenomenon is dubbed "evidence laundering" by the authors and is of yet a procedural situation that is still insufficiently discussed in legal scholarship. To analyze this phenomenon, this article begins by examining the legal nature of awarded collaboration agreements, as well as the steps of their procedure. By analyzing evidence laundering from a perspective of preserving the chain of custody of evidence, the aim is to identify the legal consequences of this phenomenon. Based on the experience of CADE's leniency program, possible measures to control this malfeasance by the prosecution are proposed. In conclusion, the article raises the possibility of establishing a single awarded collaboration center, combined with the dissemination of good practices in negotiating deals, as means to improve the evidence arising from these agreements, bringing greater legal certainty to would-be collaborators and avoiding evidence laundering.

KEYWORDS: Evidence laundering; Collaboration agreement; Wrongful process.

SUMÁRIO: 1. Introdução; 2. Considerações iniciais sobre a colaboração premiada: 2.1. A natureza jurídica da colaboração premiada como negócio jurídico processual, meio de obtenção de provas e mecanismo defensivo; 2.2. Etapas do procedimento da colaboração premiada; 3. Lavagem de provas no acordo de colaboração premiada; 
4. Quebra da cadeia de custódia da prova: consequência necessária da lavagem de provas? 5. Possíveis soluções para a lavagem de provas: o uso de lições trazidas pelo programa de leniência do CADE; 6. Conclusões; Referências.

\section{INTRODUÇÃO}

O procedimento da colaboração premiada ainda é caminho pouco trilhado pelos profissionais do sistema de justiça criminal. Apesar dos recentes desenvolvimentos teóricos e legislativos sobre a matéria, que vem ocupando espaço cada vez mais proeminente no sistema de justiça criminal brasileiro, suas peculiaridades e desafios práticos ainda são misteriosos para parcela considerável, não apenas da advocacia, como também do Ministério Público, da magistratura, das defensorias públicas e das polícias. Em razão de seu caráter negocial, a colaboração premiada não raro impõe dilemas e impasses entre as partes em negociação: acusação e defesa.

Para sua formação, o acordo de colaboração premiada inicia-se a partir de uma etapa preliminar, em que o investigado ou acusado proponente apresenta ao Ministério Público uma síntese das informações e indica os elementos de corroboração que pretende apresentar para obter como benefício uma sanção premial. Como muitas vezes esta etapa preliminar não é formalizada em um caderno procedimental, muitas destas tratativas iniciais não permanecem disponíveis para controle posterior de legalidade, possibilitando um fenômeno aqui identificado como lavagem de provas.

Propõe-se definir lavagem de provas, portanto, como a dissimulação ou a ocultação da origem de uma informação inutilizável no processo como fonte de meios de prova, a fim de conferir aparência de legitimidade à sua origem.

Ainda que este fenômeno possa ter lugar em outros momentos processuais, este artigo busca analisá-lo justamente sob sua potencial incidência na formação dos acordos de colaboração premiada. Justamente por isto, o artigo analisa inicialmente a compreensão técnica da colaboração premiada, examinando não apenas sua natureza jurídica, 
seu procedimento e a posição das partes que o celebram, como também suas estratégias e métodos, além de seus resultados endoprocessuais, como forma de compreender como a colaboração premiada é momento processual propício para a lavagem de provas.

Uma vez verificada a possibilidade de sua ocorrência no âmbito da colaboração premiada, busca-se compreender o fenômeno da lavagem de provas, a partir do conceito proposto. Serão analisados os contornos legais do fenômeno e a (i)licitude das provas dele derivadas sob a ótica de um caso hipotético, inspirado pelo decidido no MS/SP n. ${ }^{\circ} 35.693$ pela 2. ${ }^{\text {a }}$ Turma do STF.

Prosseguindo, a lavagem de provas também será examinada à luz da cadeia de custódia das provas, de modo a verificar se a obtenção — premeditada ou não - de informações fornecidas pelo aspirante a colaborador, sem a concessão de um benefício premial em troca, viola alguma regra processual penal. Por fim, apresentamos possíveis conclusões extraídas a partir da experiência do programa de leniência do CADE, observada a partir da vivência de um dos autores no Programa de Intercâmbio do CADE - Pincade.

Por tratar-se de discussão ainda incipiente na práxis dos acordos de colaboração premiada, de relativa complexidade teórica e prática, o tema da lavagem de provas merece discussão qualificada na doutrina processual penal. Desta maneira, enfatiza-se que, mais do que trazer as consequências jurídicas e as eventuais soluções definitivas, o trabalho busca explorar uma possível saída, assim como um modo de controlar a lavagem de provas na colaboração premiada, convidando a comunidade jurídica ao diálogo quanto às potenciais soluções apresentadas.

\section{Considerações INICIAIS SOBRE A COLABORAÇÃo PREMIADA}

Sob a perspectiva das autoridades públicas, o objetivo da colaboração premiada é permitir o acesso a informações privilegiadas quanto à ocorrência de um fato criminoso e do modo operandi de uma organização criminosa, a partir da perspectiva de um dos autores do próprio fato, de modo a auxiliar a identificação de provas e o desbaratamento da própria organização. A utilização do (co)autor do crime como testemunha - ou, melhor dizendo, a sua utilização para fornecimento de meios de prova 
- foi identificada por Stephen S. Trott, para quem a colaboração de um dos autores é uma das mais úteis, importantes e, de certo, indispensáveis armas para a repressão a infratores ${ }^{3}$. O autor faz um alerta em seu trabalho - com as devidas ressalvas sobre o método comparado, dadas as diferenças entre o comum procedimento de trial $^{4}$ no ordenamento americano e o processo penal brasileiro - quanto às inúmeras preocupações que há na "utilização de um criminoso como testemunha", em razão de eventuais traições, prática de perjúrios ${ }^{5}$ em série, obstrução de justiça e produção de provas falsas ${ }^{6}$. Em que pese existam preocupações com o uso de infratores como fonte de obtenção de provas, com muitos já tendo quebrado acordos de colaboração ${ }^{7}$, os benefícios desta nova téc-

3 TROTT, Stephen S. Uso de um criminoso como testemunha: um problema especial. Tradução de Sergio Fernando Moro. Revista CEJ, Brasília, Ano XI, n. 37. p. 68.

4 Para uma visão do trial no processo penal americano, ver: DRESSLER, Joshua; THOMAS III, George C. Criminal Procedure: prosecuting crime. 6.ed. Minnesota: West Academic Publishing, 2017. p. 1199-1379.

5 FERREIRA, Marco Aurélio Gonçalves. A ausência do crime de perjúrio no sistema jurídico brasileiro. Revista da SJRJ, Rio de Janeiro, v. 17, n. 29, dez. 2010, p. 143-150. No texto, o autor aponta a problemática acerca da falta de tipificação, no ordenamento brasileiro, para o acusado que falta com a verdade. Explica que no direito anglo-saxão a construção da mentira do acusado no processo é reflexo do direito de permanecer em silêncio, pois, caso resolva falar e minta, será processado também pelo crime de perjúrio. De outro modo, havendo a ausência da tipificação no direito pátrio, existe parte da doutrina que entende que a mentira está associada ao princípio da não autoincriminação, porém, concluindo que está não seria a melhor solução, uma vez que o ordenamento não tutela a mentira e, por conseguinte, seria o exercício de uma atividade que não tem respaldo no direito, portanto, configurando uma conduta ilícita. No mesmo sentido: Cf. ARAS, Vladmir. "Enganei o juiz e me dei bem”. Disponível em: <https://bit.ly/38wGbtN>. Acesso em 01 set. 2021.

6 Trott, op. cit, p. 70-72, indica dois casos de réus condenados que mentiram deliberadamente contra um acusado em troca de favores com à acusação, e resultaram em absolvição em razão da falta de fiabilidade nos depoimentos prestados: a) Caso de Denver, que se refere à história de Marion Albert Pruett; e b) Caso de John DeLorean.

7 Ver, por exemplo, o caso do doleiro Alberto Youssef. BRASIL. Supremo Tribunal Federal. Habeas Corpus n. ${ }^{\circ}$ 127.483, Relator Min. Dias Toffoli, Tribunal Pleno, Brasília, 4 fev. 2016. Disponível em: <https://bit.ly/2Ww3Tln>. Acesso em 10 fev. 2020. E, mais recente, requerimento de rescisão do acordo de colaboração no caso da JBS (que se encontra sobrestado até 06 de maio de 2020 por força de decisão do Supremo). BRASIL. Supremo Tribunal Federal. 
nica de investigação são inegáveis, inclusive porque seguem um padrão transnacional no sentido de buscar uma justiça premial.

A colaboração premiada tem por premissa o fato de a criminalidade organizada naturalmente adotar uma postura reservada na prática de seus crimes. Isso muitas vezes decorre da própria natureza dos delitos praticados: cartel, lavagem de dinheiro, determinadas práticas de corrupção, evasão de divisas, fraudes a licitações e gestão fraudulenta de empresas. Todos estes delitos pressupõem um acordo conjunto de silêncio ${ }^{8}$ acerca dos atos praticados, sendo isto o que se visa quebrar para acessar as camadas mais internas e protegidas de uma organização criminosa e possibilitar o seu desbaratamento.

Colocando em números a efetividade da nova técnica de investigação, recentemente o Ministério Público Federal apontou mais de 253 condenações, registrando a devolução de mais de R 4 bilhões por meio de 185 acordos de colaboração, possibilitando à Receita Federal o lançamento tributário na ordem de R $\$ 22,465$ bilhões, com o aumento no volume de trabalho na ordem de $1.200 \%$ desde 2014 .

\subsection{A NATUREZA JURÍDICA DA COLABORAÇÃO PREMIADA COMO NEGÓCIO JURÍDICO PROCESSUAL, MEIO DE OBTENÇÃO DE PROVAS E MECANISMO DEFENSIVO}

A origem do instituto da colaboração premiada no Direito brasileiro remonta à década de 1990, ainda sob a denominação de "delação premiada" ${ }^{10}$. No entanto, foi a partir da Lei n. ${ }^{0}$ 12.850/2013 (Lei das Organizações Criminosas), com maior disciplina legislativa, que o instituto

Petição n. ${ }^{\circ}$ 7.003, Relator Min. Edson Fachin, Brasília, 11 mar. 2020. Disponível em: <https://bit.ly/2vvLvha>. Acesso em 18 mar. 2020.

8 FONSECA, Cibele Benevides Guedes. Colaboração premiada. Bel Horizonte: Del Rey, 2017. p. 47.

9 MPF. Lava Jato completa seis anos com 500 pessoas denunciadas e números recordes em 2019. Disponível em: <https://bit.ly/2Uji6zi>. Acesso em 12 mar. 2020.

10 Vale ressaltar que, atualmente, o STF diferencia os termos "delação" e "colaboração", tratando-se a "colaboração" do negócio jurídico processual algo acordado com o Ministério Público e/ou a Polícia, e entendendo-se a "delação” como a colaboração unilateral realizada perante o juízo. Ver: BRASIL. Supremo Tribunal Federal. Agravo Regimental no Inquérito n. ${ }^{\circ} 4.436$, 
passou a ser aplicado em larga escala, o que se deveu à maior segurança jurídica em sua aplicação ${ }^{11}$.

Com o advento da Lei n. ${ }^{0}$ 13.964/2019 (Lei Anticrime), a redação da Seção I foi alterada, tendo o art. $3^{\circ}$-A disposto que o acordo de colaboração é negócio jurídico processual e meio de obtenção de prova, que pressupõe utilidade e interesse público.

A alteração legislativa confirmou o que fora decidido pelo Supremo Tribunal Federal no HC n. ${ }^{0} 127.483$, sob a relatoria do ministro Dias Toffoli, em que se afirmou a natureza de meio de obtenção de prova e negócio jurídico processual:

Uma vez que, além de ser qualificada expressamente pela lei como "meio de obtenção de prova", seu objeto é a cooperação do imputado para a investigação e para o processo criminal, atividade de natureza processual, ainda que se agregue a esse negócio jurídico o efeito substancial (de direito material) concernente à sanção premial a ser atribuída a essa colaboração $0^{12}$.

Assim, dois pontos relevantes são estabelecidos. O primeiro, é que se trata de um negócio jurídico processual. Ao contrário do usual na legislação, tratando a colaboração como um exclusivo "favor da pena"13, sua classificação como negócio jurídico reflete na constituição de partes (de um lado, o colaborador; de outro, o membro do Ministério Público ou a autoridade policial), cujo elemento nuclear de seu suporte é a exteriorização da vontade das partes, com a possibilidade, dentro dos parâmetros legais, de deliberação sobre efeitos ${ }^{14}$.

Relator Min. Edson Fachin, decisão monocrática, Brasília, 04 abr. 2021. Disponível em: < https://bit.ly/3kHuoi6>. Acesso em 01 set. 2021.

11 HARTMANN, Stefan Epírito Santo. O papel do juiz nos acordos de colaboração premiada. In: PACELLI, Eugênio; CORDEIRO, Nefi; REIS JÚNIOR, Sebastião dos (Coord). Direito penal e processual penal contemporâneos. São Paulo: Altas, 2019. p. 148.

12 BRASIL. Supremo Tribunal Federal. Habeas Corpus n. ${ }^{0}$ 127.483, Relator Min. Dias Toffoli, Tribunal Pleno, Brasília, j. 4 fev. 2016.

13 CORDEIRO, Nefi. Colaboração Premiada: caracteres, limites e controles. Rio de Janeiro: Forense, 2020. p. 23.

14 CALLEGARI, André Luís; LINHARES, Raul Marques. Colaboração Premiada: lições práticas e teóricas: de acordo com a jurisprudência do Supremo 
Segundo, constitui um meio de obtenção de prova, e não um meio de prova propriamente dito. Em outras palavras, implica que a colaboração é um meio pelo qual é destinado "à aquisição de elementos dotados de capacidade probatória” ${ }^{15}$. Assim, faz-se necessário diferenciar o que são meios de prova, e o que são meios de obtenção de prova. Segundo classificação adotada por Magalhães Gomes Filho, meios de prova são atividades ou os instrumentos por intermédio dos quais os dados probatórios (elementos de prova) são introduzidos e fixados no processo (produção da prova). Já os meios de obtenção da prova dizem respeito a certos procedimentos regulados pela lei, com o objetivo de conseguir provas materiais ${ }^{16}$.

Acerca do tema, Gustavo Badaró entende que, enquanto os meios de prova são aptos a servir diretamente ao convencimento do juiz sobre a veracidade ou não de uma afirmação fática, os meios de obtenção de prova são instrumento para a coleta de meios de prova ${ }^{17}$.

Desta maneira, o acordo de colaboração não se confunde com os elementos que são obtidos a partir da colaboração, como a entrega do material, declarações e anexos. E, neste sentido, assentou o STF que o acordo não se confunde com os depoimentos prestados pelo agente colaborador. Enquanto o acordo de colaboração é meio de obtenção de prova, os depoimentos propriamente ditos do colaborador constituem meio de prova. Porém, em razão da fragilidade da prova decorrente da palavra do colaborador, os depoimentos somente se mostrarão hábeis à formação do convencimento judicial se vierem a ser corroborados por outros meios idôneos de prova ${ }^{18}$.

Tribunal Federal. 2.ed. Porto Alegre: Livraria do Advogado, 2019. p. 26.

15 BRASIL. Supremo Tribunal Federal. Informativo STF n. ${ }^{\circ}$ 796. Brasília, 24 a 28 ago. 2020. Disponível em: <https://bit.ly/3baWETZ>. Acesso em 10 fev. 2020.

16 MAGALHÃES GOMES FILHO, Antonio. Notas sobre a terminologia da prova (reflexos no processo penal brasileiro). In: YARSHEL, Flávio Luiz; ZANOIDE DE MORAES, Maurício (orgs.). Estudos em homenagem à Professora Ada Pellegrini Grinover. São Paulo: DPJ, 2005. p. 308.

17 BADARÓ, Gustavo Henrique. Processo Penal. 2.ed. São Paulo: RT, 2013. p. 266.

18 BRASIL. Supremo Tribunal Federal. Habeas Corpus n. ${ }^{\circ}$ 127.483, Relator Min. Dias Toffoli, Tribunal Pleno, Brasília, 4 fev. 2016. Disponível em: <https:// bit.ly/2Ww3Tln>. Acesso em 10 fev. 2020. 
Em suma, ensina Vinicius Vasconcellos que o mecanismo de justiça negocial da colaboração premiada é um fenômeno complexo, visto que envolve diversos atos e situações processuais, o que ressalta a necessidade de especificação do elemento de que se está a tratar quando da análise de sua natureza ${ }^{19}$, isto é, de qual ato ou elemento dentro do todo "colaboração premiada" a ser observado.

Sem esgotar a questão, pode-se evidenciar um terceiro ponto implícito: de que se trata de um instrumento de defesa ${ }^{20}$, constituindo uma alternativa legal e legítima à disposição do réu, consectário lógico da autodefesa ${ }^{21}$. Trata-se, portanto, de um elemento importante a ser considerado dentro do jogo processual, em específico acerca da estratégia e táticas ${ }^{22}$ daquele que pretende iniciar tratativas com o Estado.

\subsection{ETAPAS DO PROCEDIMENTO DA COLABORAÇÃO PREMIADA}

Uma vez compreendida a natureza complexa da colaboração premiada, passa-se ao estudo do seu procedimento, com o fim de vislumbrar os momentos em que se verifica potencial para a possível prática da lavagem de provas.

Destaca-se que o último dos três aspectos tratados no tópico acima está diretamente relacionado ao procedimento de colaboração, visto que

19 VASCONCELLOS, Vinicius Gomes de. Colaboração Premiada no Processo Penal. 2.ed. São Paulo: RT, 2018. p. 70.

20 Cf. OLIVEIRA, Marlus Heriberto Arns de. A colaboração premiada como legítimo instrumento de defesa na seara do Direito Penal Econômico. 2016. Tese (Doutorado em Direito Econômico e Socioambiental) - Escola de Direito da Pontifícia Universidade Católica do Paraná. Curitiba, 2016.

21 SANTOS, Marcos Paulo Dutra. Colaboração (delação) premiada. Salvador: Juspodivm, 2016. p. 80.

22 Sobre o tema ensina Alexandre Morais da Rosa que: "a estratégia (o caminho escolhido pelo jogador para alcançar seus objetivos, levando em consideração a avaliação do cenário e as previsões que faz sobre os movimentos dos outros jogadores e do julgador) e as táticas (as ações/lances que cada jogador faz no decorrer da partida visando cumprir a estratégica) fornecem dupla articulação, comunicando-se a todo tempo". MORAIS DA ROSA, Alexandre. Para entender a delação premiada pela teoria dos jogos: táticas e estratégias do negócio jurídico. Florianópolis: Emodara, 2018. p. 179. 
existe uma vinculação prática entre as estratégias de defesa e a utilização do instituto da colaboração premiada. Neste sentido é que o trabalho visa demonstrar um fenômeno existente - lavagem de provas - , mas pouco comentado acerca do modelo negocial inaugurado no processo penal (institucionalizado) a partir da Lei n. ${ }^{\circ}$ 12.850/2013.

Assim, a estruturação do procedimento da colaboração premiada é, segundo Vinicius Vasconcellos, "condição indispensável para sua limitação no processo penal" ${ }^{23}$.

Destaca-se que o procedimento de colaboração premiada foi inicialmente desenvolvido a partir do Manual de Colaboração Premiada da ENCCLA (Estratégia Nacional de Combate à Corrupção e à Lavagem de Dinheiro $)^{24}$. Seguiu igualmente a Orientação Conjunta $n^{0} 1 / 2018^{25}$ do Ministério Público Federal, que visou traçar normas gerais e assegurar uniformidade na tratativa dentro do órgão. Por fim, culminou com a Lei Anticrime, dispondo em lei práticas e costumes que já vinham sendo observados e utilizados com base tanto no manual, quanto na orientação conjunta.

Para analisar o procedimento da maneira mais completa possível, bem como delimitar o objeto de estudo, partir-se-á do chamado "procedimento padrão", que tem sido a regra aplicada no contexto da Operação "Lava Jato", e que se mostra o mais eficaz, tanto para a acusação como para a defesa ${ }^{26}$. Neste quadro ideal, o acordo é negociado e realizado na fase pré-processual ${ }^{27}$, isto é, antes do início do processo.

Destaca-se a relevante classificação de Vinicius Vasconcellos, que subdivide o procedimento em quatro fases: (i) negociações; (ii)

23 VASCONCELLOS, Vinicius Gomes de. Colaboração Premiada no Processo Penal. 2.ed. São Paulo: RT, 2018. p. 199.

ENCLA. Manual de Colaboração Premiada. Estratégia Nacional de Combate à Corrupção e à Lavagem de Dinheiro. Jan. 2014. Disponível em: <https://bit. ly/3a1bQ5X>. Acesso em 19 fev. 2020.

25 MPF. Orientação Conjunta $n^{0} 1 / 2018$ acordos de colaboração premiada. Ministério Público Federal. 23 mai. 2018. Disponível em: <https://bit.ly/2U3slsG>. Acesso em 19 fev. 2020.

26 VASCONCELLOS, Vinicius Gomes de. Colaboração Premiada no Processo Penal. 2.ed. São Paulo: RT, 2018. p. 199.

27 SILVA, Eduardo Araújo da. Organizações criminosas. Aspectos penais e processuais da Lei 12.850/2013. 2.ed. São Paulo: Atlas. 2015, p. 66. 
formalização/homologação; (iii) colaboração efetiva e produção da prova; e (iv) sentenciamento e concretização do benefício ${ }^{28}$.

A despeito de a terminologia "proponente" se referir ao ator público acusatório ${ }^{29}$, a colaboração, em regra, deve iniciar com o movimento da defesa. Isso tem o condão de evitar o discurso de que o resultado da colaboração advém de pressão das autoridades envolvidas ${ }^{30}$. Tem-se nesse momento o início das negociações.

No geral, observa-se que são os atores privados que costumam procurar a autoridade para as primeiras negociações ${ }^{31}$. A partir deste primeiro contato - classificado como "tratativas prévias" 32 -, é praxe a formalização de um pré-acordo ${ }^{33}$, ou acordo de confidencialidade ${ }^{34}$. Este momento foi positivado no art. $3^{\circ}$-B pela Lei Anticrime, adotando o que já vinha sendo praticado, de modo a exigir a assinatura de um termo de confidencialidade para dar continuidade às tratativas. Isto é, trata-se de uma garantia para o colaborador, pois isso implica a impossibilidade de que a autoridade venha a desistir do acordo sem justa causa.

Neste momento, as primeiras provas são entregues à autoridade de forma a demonstrar presentes os pressupostos e os requisitos do

28 VASCONCELLOS, op. cit., p. 200.

29 Ibid., p. 199.

30 FONSECA, Cibele Benevides Guedes. Colaboração premiada. Bel Horizonte: Del Rey, 2017. No mesmo sentido: MENDONÇA, Andrey Borges de. Aspectos controvertidos da negociação da colaboração premiada na experiência brasileira. In: AMBOS, Kai; ZILLI, Marcos; MENDES, Paulo de Sousa (Org.). Colaboração Premiada: perspectiva de direito comparado. São Paulo: Tirant lo Blanch, 2020. p. 26.

${ }^{31}$ FONSECA, Cibele Benevides Guedes. Colaboração premiada. Bel Horizonte: Del Rey, 2017. p. 111.

32 GAVRONSKI, Alexandre Amaral; MENDONÇA, Andrey Borges de. Manual do Procurador da República: Teoria e Prática. 3.ed. Salvador: JusPodivm, 2017. p. 243.

33 SOUZA, Mariana M. Os limites e o controle dos acordos de colaboração premiada: o rei está nu, ou, em terra de cego, quem tem um olho é louco? In: GOMES, Luiz Flávio; SILVA, Marcelo R. Organizações Criminosas e técnicas especiais de investigação. Salvador: JusPodivm, 2015. p. 314-317.

34 MORAIS DA ROSA, Alexandre. Para entender a delação premiada pela teoria dos jogos: táticas e estratégias do negócio jurídico. Florianópolis: Emodara, 2018. p. 283. 
acordo $^{35}$. Em paralelo, estas devem instigar o Parquet a dar continuidade à negociação, de modo a não haver, de pronto, o indeferimento sumário nos termos do $\S 1^{\circ}$ do art. $3^{\circ}-\mathrm{B}$ da Lei n. ${ }^{\circ} 12.850 / 2013$.

Segundo o art. $3^{\circ}-\mathrm{C}$ da Lei n. ${ }^{\circ} 12.850 / 2013$ e seguindo a Orientação Conjunta $n^{0} 1 / 2018$, a defesa é encarregada da instrução da proposta de acordo, pois deve buscar convencer a autoridade policial ou ministerial da importância das informações e elementos de prova, a fim de subsidiá- $-0^{36}$.

De todo modo, este também não é o momento de lançar todas as cartas à mesa, e sim o de despertar interesse da autoridade. O termo inicial, metaforicamente, assemelha-se muito ao trailer de um filme: o pretenso colaborador deve mostrar uma parte do conteúdo que propõe apresentar - isto é, algumas das informações pertinentes -, ao mesmo tempo em que reserva importantes e relevantes questões para o momento propício da negociação.

Uma vez despertado o interesse da autoridade, passa-se ao segundo momento, a fase de negociação. Só então é que serão entregues minutas mais elaboradas, em complemento às informações antes retratadas. Ensina Andrey Borges de Mendonça que cabe ao Ministério Público o papel de "advogado do Diabo", procurando lacunas e falhas na versão apresentada e sempre tentando contrastar todas as declarações do potencial colaborador, com o intuito de afastar colaborações mendazes. Para tanto, podendo o membro do Parquet realizar diligências investigatórias até mesmo antes da celebração do acordo, visando confirmar e atestar as palavras do colaborador ${ }^{37}$. Após a efetiva contraprestação, com todas as informações lançadas, as partes passam à discussão acerca do prêmio a ser concedido ao colaborador. O benefício será considerado, levando em consideração os critérios inicialmente desenvolvidos pela Corte de

35 COSTA, Leonardo Dantas. Delação Premiada. A atuação do Estado e a relevância da voluntariedade do colaborador com a justiça. Curitiba: Juruá, 2017. p. 144.

36 CALLEGARI, André Luís; LINHARES, Raul Marques. Colaboração Premiada: lições práticas e teóricas: de acordo com a jurisprudência do Supremo Tribunal Federal. 2.ed. Porto Alegre: Livraria do Advogado, 2019. p. 62.

37 MENDONÇA, Andrey Borges de. Aspectos controvertidos da negociação da colaboração premiada na experiência brasileira. In: AMBOS, Kai; ZILLI, Marcos; MENDES, Paulo de Sousa (Org.). Colaboração Premiada: perspectiva de direito comparado. São Paulo: Tirant lo Blanch, 2020. p. 31. 
Cassação Italiana ${ }^{38}$, avaliando-se 0 acordo com a robustez das informações apresentadas, com a apresentação de detalhes dos crimes praticados, de documentos fidedignos e elementos de provas relevantes ${ }^{39}$.

Após, passa-se à fase de formalização e homologação, com a elaboração do termo de colaboração premiada, nos termos dos $\S \S 6^{\circ}$ e $7^{\circ}$ do art. $4^{\circ}$ da Lei do Crime Organizado, momento em que o judiciário passará a atuar, fazendo o controle de regularidade, voluntariedade e legalidade ${ }^{40}$.

E, por fim, há a última fase, a de sentenciamento e concretização do benefício, momento em que o juiz passará, de fato, a impor a sanção premial ${ }^{41}$ acordada pelas partes de modo a conceder o benefício ao colaborador.

38 "a) Em primeiro lugar deve-se verificar a credibilidade do declarante, através de dados como sua personalidade, seu passado, sua relação com os acusados, o motivo de sua colaboração; b) posteriormente analisa-se a confiabilidade intrínseca ou genérica da declaração auferida da sua seriedade, precisão, coerência, constância e espontaneidade; c) por último, valoram-se a existência e a consistência das declarações com o confronto das demais provas, ou seja, atesta-se a confiabilidade extrínseca ou específica da declaração.” BITTAR, Walter B. Delação premiada: direito, doutrina e jurisprudência. São Paulo: Tirant Lo Blanch, 2020. p. 223. No mesmo sentido, ver: GAVRONSKI, Alexandre Amaral; MENDONÇA, Andrey Borges de. Manual do Procurador da República: Teoria e Prática. 3.ed. Salvador: JusPodivm. 2017, p. 251. PEREIRA, Frederico V. Delação Premiada: legitimidade e procedimento. Curitiba: Juruá, 2019. p. 241-246.

39 CALLEGARI, André Luís; LINHARES, Raul Marques. Colaboração Premiada: lições práticas e teóricas: de acordo com a jurisprudência do Supremo Tribunal Federal. 2.ed. Porto Alegre: Livraria do Advogado, 2019. p. 65.

40 Ver HARTMANN, Stefan Epírito Santo. O papel do juiz nos acordos de colaboração premiada. In: PACELLI, Eugênio; CORDEIRO, Nefi; REIS JÚNIOR, Sebastião dos (Coord). Direito penal e processual penal contemporâneos. São Paulo: Altas, 2019; ZILLI, Marcos. Transplantes, traduções e cavalos de troia. O papel do juiz no acordo de colaboração premiada. Leituras à luz da Operação Lava Jato. In: AMBOS, Kai; ZILLI, Marcos; MENDES, Paulo de Sousa. (Org.). Corrupção: ensaios sobre a Operação Lava Jato. São Paulo: Marcial Pons, 2019. p. 120-128; PEREIRA, Frederico Valdez. Eficácia da colaboração premiada e controle judicial. Homologação e sentenciamento. In: GEBRAN NETO, João Pedro (Org.). Colaboração premiada: perspectivas teóricas e práticas. Porto Alegre: Verbo Jurídico, 2020. p. 137-143.

${ }^{41}$ WUNDERLICH, Alexandre. "Sanção premial diferenciada" após o pacote "anticrime". ConJur, 9 jan. 2020. Disponível em: <https://bit.ly/3v8QBKs>. Acesso em 9 mar. 2021. 


\section{LaVAgem de provas no acordo de colaboraÇÃo PREMIADA}

Conforme se expôs na seção anterior, o acordo de colaboração premiada regido pela Lei n. ${ }^{\circ} 12.850 / 2013$ apresenta algumas importantes características: (i) pode ser realizado em qualquer fase do processo; (ii) a autoridade não está limitada a uma única negociação que verse sobre os mesmos fatos; e (iii) a autoridade que negocia é a mesma que gere as provas e que processa o colaborador.

Até este ponto, o trabalho se dedicou a apresentar algumas das características da colaboração premiada - necessárias à compreensão do tema proposto - , com ênfase no procedimento de entabulação do acordo, momento propício àquilo que se identifica como lavagem de provas.

Por lavagem de provas, entende-se a dissimulação ou a ocultação da origem da informação inutilizável no processo como fonte de novos meios de prova, a fim de conferir aparência de legitimidade à sua origem. Trata-se, portanto, de um processo ${ }^{42}$ em que ocorre a transformação do elemento, da evidência ou da informação inutilizável em um dado útil e aproveitável nos autos.

A fim de facilitar a compreensão do tema, o fenômeno pode ser mais bem observado a partir de um exemplo. Imagine-se que, em uma investigação, identifique-se uma organização criminosa composta por cinco empresários, cujo objetivo era, mediante o pagamento de propina, fraudar licitações de maneira a se manterem hegemônicos no mercado. Imagine-se também que o produto do ilícito tinha a sua origem e titularidade dissimulados pelo uso de empresas offshore.

A partir das primeiras diligências de investigação, terá havido quebra de sigilo telefônico e telemático, o que acaba por subsidiar a deflagração de operação, contando com mandados de busca e apreensão, bem como mandados de prisão temporária dos cinco empresários. Sabendo-se da existência de fortes indícios de atividade delitiva nos materiais apreendidos, dando conta de reiterada prática criminosa, dois dos cinco empresários, por recomendação de seus respectivos advogados, buscam o Ministério Público para a propositura de um acordo de colaboração

42 Semelhante à lavagem de bens e capitais, por isso a inspiração na denominação do fenômeno. 
premiada. O MP, embora já de posse de informações suficientes para a desarticulação desta organização criminosa, percebeu, na busca, que os agentes possuíam outras informações relevantes do modus operandi da organização, bem como outras informações que poderiam levar ao desbaratamento de outras organizações criminosas conexas. Por isso, dá início a tratativas com os dois potenciais colaboradores que, por sua vez, apresentam documentos relevantes que corroboram outros dados já arrecadados, de modo a guiar novas diligências em investigações que já estavam em curso, bem como auxiliam na compreensão da estrutura organizacional e na interpretação dos inúmeros documentos coletados.

Ciente de haver aí um caso hipotético, observa-se que a autoridade ministerial, em razão das tratativas, logra melhor compreender a estrutura da organização criminosa, realizar o filtro das informações apresentadas, bem como tomar conhecimento de outras infrações e do modus operandi da organização criminosa investigada.

Destaca-se que, se encerradas as tratativas neste momento, as provas não poderão ser utilizadas pela autoridade para qualquer outra finalidade ${ }^{43}$. No entanto, as informações prestadas no âmbito do pré-acordo e da negociação - isto é, os elementos informativos - acabam por conferir à autoridade maior grau de conhecimento acerca dos fatos, passando ela a compreender a estrutura da organização criminosa, o que facilita a filtragem das demais informações obtidas no curso das investigações.

A partir do término das negociações e da entrega dos elementos e das informações pelos colaboradores, extraem-se três possíveis condutas que podem ser adotadas pela autoridade negociante.

Em uma primeira hipótese, a autoridade pode simplesmente dar continuidade às tratativas, fixar e negociar os benefícios e, ao final, assinar o acordo de colaboração. Esta é a resolução mais simples, usual e lógica do procedimento de acordo de colaboração premiada, com todas as informações e elementos apresentados sendo úteis nos autos, não havendo necessidade de serem "lavados" pela acusação. Isso quer dizer:

43 Positivada pelo $\$ 6^{\circ}$, do art. $3^{\circ}$-B da Lei n. ${ }^{\circ} 12.850 / 2013$, com alteração pela Lei Anticrime, bem como já estava prevista na Orientação Conjunta $\mathrm{n}^{0}$ 1/2018 do MPF. MPF. Orientação Conjunta $n^{o} 1 / 2018$ acordos de colaboração premiada. Ministério Público Federal. 23 mai. 2018. Disponível em: <https:// bit.ly/2U3slsG>. Acesso em 19 fev. 2020. 
no procedimento padrão em que o desfecho da negociação é a elaboração do acordo, não se vislumbra o fenômeno da lavagem de provas, ante sua desnecessidade.

Contudo, nem todas as tratativas de colaboração resultam efetivamente na celebração de um acordo. É aqui que reside o perigo ora em exame.

Pensando em uma segunda hipótese para a acusação, em caso de as negociações e documentos apresentados não resultarem em acordo, poderá a autoridade encerrar as tratativas, apresentando justa causa, mas se aproveitar das informações que obteve confidencialmente, ainda que sem acesso aos materiais.

No modelo adotado pelo Brasil, em que a autoridade que negocia é a mesma que investiga e processa criminalmente, quando prestadas as declarações pelo colaborador, é impossível restituir as partes ao status quo ante. Ou seja, o membro do Ministério Público que teve contato com as informações não vai simplesmente esquecer ou deletar as informações e provas com as quais teve contato.

Utilizando o caso hipotético, suponha-se que, durante a análise dos materiais fornecidos pelo potencial colaborador, o Ministério Público tenha obtido acesso a uma planilha que descreve a divisão de valores ilícitos distribuídos entre os integrantes de uma organização criminosa. No entanto, em vez de nominar os beneficiários, a planilha utiliza-se de siglas, o que dificulta a identificação dos favorecidos no esquema fraudulento. Suponha-se que se tenha verificado, ao fim da investigação, que ainda resta um único beneficiário que a autoridade desconhece, posto que, com as informações coletadas até então, não se obteve sucesso em decifrar a sigla.

Supondo-se, igualmente, que em uma das negociações conduzidas pelo Parquet o pretenso colaborador informe o nome do último beneficiário e aponte uma conta bancária no exterior que confirme a transação de valores, a autoridade, mesmo que restitua ao interessado todos os documentos fornecidos no caso de encerramento das tratativas, ainda assim conhecerá a identidade do investigado e saberá como obter os elementos de prova necessários e aptos a comprovar o envolvimento do investigado restante. Assim, nesta segunda hipótese de desfecho das negociações, pode existir o fenômeno de lavagem de provas - ainda 
que involuntário -, posto que decorre de algo que chegou ao efetivo conhecimento da autoridade negociante.

Pode-se indicar, por fim, uma terceira possibilidade de desfecho. Suponha-se que a autoridade venha a se utilizar dos materiais apresentados ainda durante as negociações dos acordos dos pretensos colaboradores. Isto é, voltando-se ao caso hipotético, imagine-se que um dos empresários colaboradores tenha, para além das condutas já investigadas da organização criminosa, conhecimento e informações sobre práticas dos investigados de corrupção de alguns agentes públicos. E que, embora tais condutas fossem de conhecimento e alvo de investigação do Ministério Público, ainda careciam de uma linha investigativa clara e efetiva.

Durante as tratativas, um dos colaboradores elabora anexos, fornece conversas de aplicativo de mensagens instantâneas e expõe todo seu conhecimento acerca do modus operandi que, de fato, aponta ao Parquet uma nova linha investigativa que se mostra extremamente frutífera para desvendar as práticas investigadas. E, a partir destas informações apresentadas o Ministério Público passa a diligenciar, obtendo elementos equivalentes de forma cruzada ou de maneira independente, que suprem a conversa apresentada, e que podem ser utilizados em posterior ação penal.

Ao término da negociação, quando todas as informações e meios de prova tenham sido obtidos (esgotando-se a fonte útil de inteligência ${ }^{44}$ ), é possível que o membro do Ministério Público opte por declinar o acordo de colaboração. Para tanto, pode justificar que, para a investigação em curso, o acordo não é útil nem necessário, visto que já havia provas suficientes para esclarecimento dos fatos da investigação. Complementa a

${ }_{44}$ Entende-se por inteligência "a atividade realizada pela polícia ou pelo Ministério Público, com a finalidade de desvendar uma prática criminosa". Sua finalidade é a de "buscar elementos de convicção a respeito do fato ilícito, antijurídico e culpável" e que "deseja, sobretudo, possibilitar o uso ostensivo e, como regra, público da informação gerada para a responsabilização do agente criminoso por meio da ação penal pública”. TINÔCO, Lívia Nascimento. Prova e conhecimento, investigação criminal e inteligência: uma distinção necessária. In: SALGADO, Daniel de Resende; QUEIROZ, Ronaldo Pinheiro de; KIRCHER, Luís Felipe Schneider (coords.). Altos estudos sobre a prova no processo penal. Salvador: JusPodivm, 2020. p. 164-184. 
justificativa, sob o argumento de que não há um dever de disclosure ${ }^{45}$ por parte da acusação, visto que seu declinar também decorre de informações sigilosas, que não podem ser trazidas ao colaborador, sob pena de frustrar outras investigações em curso.

Resta claro que, nesta terceira hipótese, ainda durante a negociação, houve o fenômeno da lavagem de provas, especialmente quando o membro do Ministério Público obteve "as fontes independentes" de prova, suprindo as informações trazidas pelo colaborador.

Desta maneira, resta também demonstrado que o fenômeno da lavagem de provas é plenamente possível na prática, especialmente durante as negociações de acordos de colaboração premiada. Visando complementar a reflexão acerca do tema, analisa-se o seguinte caso concreto que serviu de inspiração para o trabalho.

No Agravo Regimental em Mandado de Segurança n. ${ }^{0}$ 35.693, impetrado contra ato da Procuradoria Geral da República, a $2^{\text {a }}$ Turma do STF reafirmou que o acordo de colaboração premiada constitui negócio jurídico processual personalíssimo, cuja conveniência e oportunidade não se submetem ao escrutínio do Estado-juiz. Conclui-se, portanto, não haver direito líquido e certo que possa ser invocado para compelir o Ministério Público à celebração do acordo de colaboração premiada ${ }^{46}$.

No caso, o réu alegou ter havido demora do Ministério Público em concluir a fase de negociação do acordo. Logo após, tendo havido recusa

45 Segundo Andrey Borges de Mendonça, o Ministério Público não tem o dever de informar todas as provas que possui em desfavor do colaborador, tampouco trazer à tona investigações que porventura conduza em paralelo, devido ao risco de que, caso chancelado o dever, isso geraria o fenômeno indesejado de colaboradores iniciarem tratativas apenas com o fim de descobrirem provas e elementos que o Parquet possui (MENDONÇA, Andrey Borges de. Aspectos controvertidos da negociação da colaboração premiada na experiência brasileira. In: AMBOS, Kai; ZILLI, Marcos; MENDES, Paulo de Sousa (Org.). Colaboração Premiada: perspectiva de direito comparado. São Paulo: Tirant lo Blanch, 2020. p. 30-45). Assim, o dever de motivação do Ministério Público nas negativas de acordo encontra o mesmo problema do acesso integral às colaborações premiadas: o binômio entre sigilo decorrente de investigações em curso e a garantia de acesso às informações pela defesa.

BRASIL. Supremo Tribunal Federal. Informativo STF n. ${ }^{\circ} 942$. Brasília, 27 a 31 mai. 2019. Disponível em: <https://bit.ly/2WAX5TB>. Acesso em 28 de fev. 2020. 
da proposta pela autoridade, a defesa impugnou a decisão ministerial visando compelir o Parquet a efetivar as negociações tratadas no âmbito de negociação, culminando com a assinatura do acordo de colaboração premiada. Segundo a defesa, foram realizadas ao todo treze reuniões prévias em Brasília, ao longo de dezessete meses, incluindo três entrevistas com o réu, além de ter sido entregue material contendo descrição de condutas criminosas que resultaram na elaboração e entrega de quarenta anexos ${ }^{47}$.

De outro lado, o Ministério Público justificou sua recusa em decorrência de que os elementos de corroboração e de prova apresentados não apresentavam a consistência necessária à elucidação dos fatos: não eram conclusivos para confirmar as irregularidades relatadas ${ }^{48}$.

O que se depreende do caso é que, independentemente da recusa ou aceite na formalização do acordo, a quantidade de informações prestadas ao Parquet - pelo período superior a um ano de negociação - proporcionou à acusação inúmeros elementos que muito provavelmente não teriam sido obtidas de outro modo ou, pelo menos não com o mesmo nível de detalhamento. Na mesma esteira, observando-se apenas os dados disponíveis quanto ao caso $^{49}$, somadas à decisão do Supremo, verifica-se que estar equivocadamente se firmando a tese de que Ministério Público teria absoluta discricionariedade em propor, deixar de propor, dar seguimento ou desistir de acordos de colaboração ${ }^{50}$. Em oposição,

47 POMPEU, Ana. MP não é obrigado a formalizar acordo de delação, decide $2^{\mathrm{a}}$ Turma do STF. Consultor Jurídico. 28 mai. 2019. Disponível em: <https://bit. ly/2Ujlb2k>. Acesso em 28 de fevereiro de 2020.

48 Ibid.

49 Visto que ainda está revestido por segredo de justiça.

50 Esta visão não está dissociada de críticas doutrinárias, ainda, contando com a limitação decorrente dos $\S \S 1 .^{\circ}$ e $2 .^{\circ}$ do art. 3. ${ }^{\circ}$-B da Lei n. $.^{\circ} 12.850 / 2013$, que determinam (i) a motivação na análise sumária e (ii) a justa causa após o termo de confidencialidade, quando houver recusa por parte do Parquet. Assim, muito embora os integrantes do MP tenham o dever constitucional de apontarem os fundamentos jurídicos em suas manifestações (art. 129, VIII, $\S 4^{\circ}, \mathrm{CF}$ ), o STF confere ao Parquet a análise e a palavra final acerca da celebração, ou não, do acordo. Ver MENDONÇA, Andrey Borges de. Aspectos controvertidos da negociação da colaboração premiada na experiência brasileira. In: AMBOS, Kai; ZILLI, Marcos; MENDES, Paulo de Sousa (Org.). Colaboração Premiada: perspectiva de direito comparado. São Paulo: Tirant lo Blanch, 2020. p. 30-45. 
considerando-se que a atuação do Ministério Público está pautada pela legalidade ${ }^{51}$, estando presentes os pressupostos e requisitos autorizadores da celebração de acordo, não haveria que se falar em juízo de oportunidade e conveniência, permitindo que o membro do MP possa escolher com quem celebrar acordo de colaboração e com quem não o fazer. ${ }^{52}$

De todo modo, em se tratando o acordo de colaboração premiada de um negócio jurídico, há de prevalecer a vontade das partes - acusação $e$ defesa -, de modo que sua celebração não possa ser imposta pelo Judiciário. ${ }^{53}$ Assim, caso impassível o Ministério Público e havendo interesse da defesa em obter algum benefício por sua colaboração, poderá recorrer à tentativa de reconhecimento da delação unilateral, nos termos do art. 4. ${ }^{\circ}$ da Lei n. ${ }^{\circ} 12.850 / 2013$, aceita atualmente tanto pela doutrina quanto pela jurisprudência do $\mathrm{STF}^{54}$.

51 FIGUEIREDO DIAS, Jorge de. Direito processual penal. Coimbra: Coimbra, 1974. p. 126-127.

52 Para análise semelhante a respeito da colaboração premiada, ver LUCCHESI, Guilherme Brenner; ARNS DE OLIVEIRA, Marlus H. Sobre a discricionariedade do Ministério Público no ANPP e o seu controle jurisdicional: uma proposta pela legalidade. Boletim IBCCRIM, São Paulo, ano 29, n. 344, p. 26-28, jul. 2021.

53 Neste sentido, ver MENDONÇA, Andrey Borges de. Aspectos controvertidos da negociação da colaboração premiada na experiência brasileira. In: AMBOS, Kai; ZILLI, Marcos; MENDES, Paulo de Sousa (Org.). Colaboração Premiada: perspectiva de direito comparado. São Paulo: Tirant lo Blanch, 2020. p. 24. Por outro lado, defende-se que, estando presentes os pressupostos e requisitos para a celebração de acordo, ainda que não se possa falar em um direito subjetivo do acusado à colaboração, poderá a defesa requerer ao juízo o controle da legalidade da justificativa quanto à eventual recusa. Nestes termos, ver LUCCHESI, Guilherme Brenner; ARNS DE OLIVEIRA, Marlus H. Sobre a discricionariedade do Ministério Público no ANPP e o seu controle jurisdicional: uma proposta pela legalidade. Boletim IBCCRIM, São Paulo, ano 29, n. 344, p. 26-28, jul. 2021.

MENDONÇA, Andrey Borges de. Aspectos controvertidos da negociação da colaboração premiada na experiência brasileira. In: AMBOS, Kai; ZILLI, Marcos; MENDES, Paulo de Sousa (Org.). Colaboração Premiada: perspectiva de direito comparado. São Paulo: Tirant lo Blanch, 2020. p. 45; BRASIL. Supremo Tribunal Federal. Agravo Regimental no Inquérito n. ${ }^{\circ} 4.436$, Relator Min. Edson Fachin, decisão monocrática, Brasília, 04 abr. 2021. Disponível em: < https://bit.ly/3kHuoi6>. Acesso em 01 set. 2021. 
$\mathrm{O}$ entendimento quanto à inexistência de um direito líquido e certo do imputado à conclusão de um acordo, aliado à jurisprudência permissiva à pretensa discricionariedade do Ministério Público em sua celebração, resulta em um ambiente propício à lavagem de provas. Quando premeditada a lavagem, permite-se que o procedimento de colaboração premiada seja utilizado para obter novas informações e fontes de provas, além de diminuir a capacidade reativa das defesas, tornando o instituto da colaboração - que deveria ser instrumento legítimo de defesa - em algo desfavorável ao colaborador. E, mesmo não havendo premeditação, na hipótese em que, de fato, as tratativas preliminares não permitirem a apuração de elementos suficientes para justificar que um acordo seja firmado, ainda assim terá havido um ganho para a acusação — facilitando a análise dos elementos de prova ou direcionando os esforços de investigação - que não se traduz em um benefício correspondente à defesa.

A partir destas constatações e apontamentos, é necessário investigar as implicações processuais da lavagem de provas, sobretudo se o fenômeno da lavagem de provas configura ilicitude em todos os casos em que esteja presente, nos termos do art. 157 do CPP e $\S 6^{\circ}$ do art. 3-B da Lei n. ${ }^{\circ}$ 12.850/2013, bem como se isso afeta, ou não, a cadeia de custódia da prova.

\section{Quebra dA CADEIA DE CUSTÓdIA DA PROVA: CONSEQUÊNCIA NECESSÁRIA DA LAVAGEM DE PROVAS?}

Em nome do aprimoramento das técnicas de investigação de crimes imputados a organizações criminosas, tem se admitido a obtenção de provas por métodos ocultos - como é o caso da colaboração premiada -, que aumentam a disparidade na capacidade investigativa das partes. Isto representa (ainda) maior desequilíbrio na paridade de armas entre a atuação defensiva e a acusatória, pois a acusação passa a dispor de mecanismos muito mais amplos e efetivos de investigação ${ }^{55}$. Dada a natureza

55 Acerca do tema, vale ressaltar a presente discussão acerca da investigação defensiva, introduzida pelo provimento 188/18 do Conselho Federal da $\mathrm{OAB}$, como forma de tentar reestabelecer a paridade de armas entre acusação e defesa. OAB. Provimento $n^{\circ}$ 188/18 de dezembro de 2018. Regulamenta 
própria inquisitória dos procedimentos investigativos ${ }^{56}$, demonstra-se um campo de preocupação baseado na possibilidade da inserção de provas ilícitas ou inutilizáveis no processo.

Devido a este fenômeno, deve haver, segundo Geraldo Prado, um rigoroso sistema de controles epistêmicos no processo. Esses controles têm relevada importância sobretudo no processo penal, uma vez que se verifica o crescente uso de métodos ocultos de investigação, como interceptação das comunicações e quebras de sigilo. De modo geral, a totalidade destes elementos informativos acaba por subsidiar acusações ${ }^{57}$ e sentenças condenatórias. Além disso, muitas dessas diligências permanecem obscuras e sem acesso pela defesa.

Recorrentemente, as medidas processuais de obtenção de provas por meios obscuros resultam em diversas diligências simultâneas, muitas das quais não se encontram concluídas quando de eventual pedido de acesso pela defesa. A título de exemplo, o STF na Reclamação n. ${ }^{\circ}$ 30.742/ SP entendeu haver necessidade de conceder à defesa acesso aos autos de acordo de colaboração premiada já homologado judicialmente, nos termos da Súmula Vinculante n. ${ }^{0} 14 .^{58}$ Contudo, ao mesmo tempo, ressalvou o acesso em caso de haver diligências investigativas em curso que possam

o exercício da prerrogativa profissional do advogado de realização de diligências investigatórias para instrução em procedimentos administrativos e judiciais. Ordem dos Advogados do Brasil. 31, dez. 2018. Disponível em: $<$ https://bit.ly/2Wp3X6f>. Acesso em 25 fev. 2020. Ver, neste sentido: SILVA, Franklyn Roger Alves. Investigação Criminal Direta pela Defesa. Salvador: Juspodivm, 2019; MACHADO, André Augusto Mendes. Investigação Criminal Defensiva. São Paulo: Revista dos Tribunais, 2010; MORAES, Rafael Francisco Marcondes de; PIMENTEL JÚNIOR, Jaime. Polícia Judiciária e a atuação da defesa na investigação criminal. 2.ed. Salvador: Juspodivm, 2018; PEREIRA, Gustavo Alberine. Investigação defensiva no Brasil: limites e possibilidades no processo penal brasileiro. Dissertação (Mestrado) - Programa de Pós-Graduação em Direito, PUCRS. Porto Alegre, 2019. Disponível em: < https://bit. ly/38ynA0s>. Acesso em 01. set. 2021.

56 LOPES JR., Aury. Fundamentos do Processo Penal: introdução crítica. São Paulo: Saraiva, 2015. p. 153-155.

57 PRADO, Geraldo. Prova penal e sistema de controles epistêmicos: a quebra da cadeia de custódia das provas obtidas por métodos ocultos. São Paulo: Marcial Pons, 2014. p. 43.

58 "É direito do defensor, no interesse do representado, ter acesso amplo aos elementos de prova que, já documentados em procedimento investigatório 
ser prejudicadas ${ }^{59}$. E esta tende a ser a realidade na maior parte dos casos de colaboração premiada - e de outras medidas de investigação -, o que pode inviabilizar o contraditório pleno ${ }^{60}$.

A busca por disponibilidade de informações à defesa como forma de controle epistêmico teve início na década de 1970 nos Estados Unidos da América, a partir da Rule 16 das Federal Rules of Criminal Procedure ${ }^{61}$. Neste contexto, a legitimação das decisões penais acabou por ser condicionada à estreita observância das regras dirigidas à paridade de armas, evocada como premissa fundamental de um fair trial. Acerca do tema, ensinam Dressler e Thomas III acerca dos direitos da defesa, ainda na fase de pre-trial:

Os defensores [no tribunal federal] têm uma regra de procedimento correta para descobrir os vários elementos de provas. Além disso, [...] os réus têm o devido processo legal para descobrir todos os elementos de prova exculpatórios nas mãos do promotor. A oitiva vigorosa das testemunhas de acusação em audiência preliminar, como vimos, também pode ser uma ferramenta eficaz. [...] Assim, embora a descoberta ocorra nos estágios de pré-julgamento

realizado por órgão com competência de polícia judiciária, digam respeito ao exercício do direito de defesa."

59 BRASIL. Supremo Tribunal Federal. Informativo STF n. ${ }^{\circ}$ 937. Brasília, 8 a 19 abri. 2019. Disponível em: <https://bit.ly/2UhuzmZ>. Acesso em em 28 de fev. 2020.

${ }^{60}$ Neste sentido, dentre os documentos cedidos pelo colaborador, "os anexos são divididos por fatos - ou seja, não se faz uma narrativa única com todos os fatos -, com o intuito de permitir que investigações independentes possam ser mantidas em sigilo no futuro". MENDONÇA, Andrey Borges de. Aspectos controvertidos da negociação da colaboração premiada na experiência brasileira. In: AMBOS, Kai; ZILLI, Marcos; MENDES, Paulo de Sousa (Org.). Colaboração Premiada: perspectiva de direito comparado. São Paulo: Tirant lo Blanch, 2020. p. 26. No mesmo sentido: GAVRONSKI, Alexandre Amaral; MENDONÇA, Andrey Borges de. Manual do Procurador da República: Teoria e Prática. 3.ed. Salvador: JusPodivm, 2017. p. 247. Desta maneira, sob a ressalva do decidido pelo STF, é possível que o acesso ao conteúdo pelas defesas nem sempre seja possível de forma integral - assim recorrentemente verificado na praxe forense -, sob o argumento de macular investigações em curso.

${ }_{61}$ PRADO, Geraldo. Prova penal e sistema de controles epistêmicos: a quebra da cadeia de custódia das provas obtidas por métodos ocultos. São Paulo: Marcial Pons, 2014. p. 53. 
de um processo criminal, seu real valor é para o julgamento e para a barganha que é um substituto para o julgamento - os réus obtêm pechinchas muito melhores se tiverem uma defesa razoavelmente forte ${ }^{62}$.

Vale ressaltar que a Rule 16(a)(1)(E) também obriga a acusação a fornecer quaisquer fotos de livros, papéis, documentos, datas, fotografias, objetos tangíveis, construções ou lugares, cópias ou porções de quaisquer itens que estiverem em seu poder ${ }^{63}$.

O que se quer evitar com estas determinações são as antigas e comuns provas ditas "carried in the dark" ${ }^{4}$, isto é, ocultadas da parte adversa a partir de um conjunto de manobras visando surpreender a outra parte e obter vantagem estratégica processual. A forma mais comum de evitar conhecimento da prova no processo americano se dava pela introdução de provas desconhecidas pela parte adversa (unfair surprise) sem que esta pudesse conhecer o meio de sua obtenção. ${ }^{65}$

Assim, foi criado o mecanismo de discovery, com o fim de instituir a possibilidade de especificar, examinar e conseguir todos os meios de prova destinados a serem produzidos antes da fase do trial. Esse sistema de descoberta das fontes de prova (discovery devices) assegura à parte tomar conhecimento das provas que a outra pretende produzir e de como foram obtidas, podendo controlar a legalidade do acesso às fontes

62 DRESSLER, Joshua; THOMAS III, George C. 2017, p. 966. Original “Defendants [in federal court] do have a rule of procedure right to discover various items of evidence. Moreover, [...] defendants have a due process right to discover all exculpatory evidence in the hands of the prosecutor. Vigorous cross-examination of the prosecution witnesses at preliminary hearing, as we have seen, can also be an effective discovery tool. [...] Thus, although discovery occurs in the pretrial stages of a criminal prosecution, its real significance is for the trial and the plea bargaining that is a surrogate for trial - defendants get much better bargains if they have a reasonably strong defense". LII. Legal Information institute. Rule 16. Discovery and Inspection. Disponível em: <https://bit.ly/397xEeY>. Acesso em 28 fev. 2020. Em português, literalmente, "carregadas no escuro".

PRADO, Geraldo. Prova penal e sistema de controles epistêmicos: a quebra da cadeia de custódia das provas obtidas por métodos ocultos. São Paulo: Marcial Pons, 2014. p. 56. 
de prova ${ }^{66}$. Em outras palavras, a discovery é um mecanismo que busca aferir a cadeia de custódia das provas, de modo a permitir o controle principalmente por parte da defesa, no processo penal - da fiabilidade dos elementos de prova, bem como da legalidade em sua obtenção, a fim de manter a higidez do sistema democrático de persecução penal. Neste mesmo sentido, é precisa a lição de Robert A. Doran:

A cadeia de custódia é um processo usado para manter e documentar a história cronológica das evidências físicas. [...] A modificação dos procedimentos informais de manuseio de evidências das agências policiais pode ser necessária, mas as leis relativas ao manuseio e gerenciamento de evidências devem sempre ser seguidas. Muitas investigações policiais importantes são baseadas principalmente em evidências físicas circunstanciais; portanto, a cadeia de custódia tornou-se um elemento cada vez mais importante na ação penal. Isso garantirá a integridade das evidências e reduzirá as alegações de violação, roubo, plantio e contaminação das evidências. ${ }^{67}$.

A maior preocupação, na realidade, não é propriamente com a boa-fé das agências de persecução no manuseio da prova, mas a viabilidade no exercício do direito de defesa e da fiscalização por parte do judiciário na legalidade dos elementos obtidos ${ }^{68}$.

66 Ibid., p. 54.

67 DORAN, Robert A. Exploring the links in the chain of custody. In: Nebraska Association for Property and Evidence (NAPE) Annual Training Conference, 2005. Disponível em: <https://bit.ly/2xHKl2P>. Acesso em 10 mar. 2020. Original "The chain of custody is a process used to maintain and document the chronological history of physical evidence. [...] Modification of police agencies informal evidence handling procedures may be necessary, but the laws relating to evidence handling and management must always be followed. Many major police investigations are based primarily upon physical-circumstantial-evidence; therefore, the chain of custody has become an increasingly more important element in prosecuting criminal cases. This will ensure the integrity of the evidence and reduce allegations of tampering, theft, planting and contamination of evidence".

68 PRADO, Geraldo. Prova penal e sistema de controles epistêmicos: a quebra da cadeia de custódia das provas obtidas por métodos ocultos. São Paulo: Marcial Pons, 2014. p. 83. 
Aproximando o instituto ao direito pátrio, destaca-se que a discussão acerca da quebra da cadeia de custódia foi inaugurada no Brasil a partir do Habeas Corpus n. ${ }^{\circ}$ 160.662-RJ, em que a defesa alegou o desaparecimento do material obtido por meio da interceptação telemática e de parte dos áudios telefônicos interceptados nas dependências da Polícia Federal, sem que defesa, Ministério Público ou Judiciário os conhecessem ou exercessem qualquer controle ou fiscalização. Assim, a 6 . $^{\text {a Turma do }}$ Superior Tribunal de Justiça reconheceu a tese de nulidade pela quebra da cadeia de custódia, declarando a ilicitude da prova e de outras provas dela derivadas ${ }^{69}$. Desta forma, evidencia-se uma possível ilegalidade das provas obtidas, o que afetaria também as provas derivadas. Atualmente, esta matéria está disciplinada nos arts. 158-A a 158-F do Código de Processo Penal, introduzidos pela Lei n. ${ }^{0}$ 13.964/2019.

A cadeia de custódia das provas tem um papel importante para se evitar a lavagem de provas. O ordenamento brasileiro veda qualquer uso de provas ilícitas, bem como as suas derivadas (art. 5. ${ }^{\circ}$, LVI, CR; art. 157, CPP). E, são consideradas ilícitas as provas obtidas em violação a normas constitucionais ou legais. No âmbito da colaboração premiada, está disposto expressamente no o § $6 .^{\circ}$ do art. 3-B da Lei n. ${ }^{\circ} 12.850 / 2013$ :

Art. $3^{\circ}$-B. O recebimento da proposta para formalização de acordo de colaboração demarca o início das negociações e constitui também marco de confidencialidade, configurando violação de sigilo e quebra da confiança e da boa-fé a divulgação de tais tratativas iniciais ou de documento que as formalize, até o levantamento de sigilo por decisão judicial.

$[\ldots]$

$\S 6^{\circ}$ Na hipótese de não ser celebrado o acordo por iniciativa do celebrante, esse não poderá se valer de nenhuma das informações ou provas apresentadas pelo colaborador, de boa-fé, para qualquer outra finalidade.

69 BRASIL. Superior Tribunal de Justiça. Habeas Corpus n. ${ }^{0}$ 160.662, Relatora Min. Assusete Magalhães, $6^{\mathrm{a}}$ Turma, Brasília, 17 mar. 2014. Disponível em: <https://bit.ly/2ITUsnI $>$. Acesso em 10 fev. 2020. 
Como se vê, o legislador considera ilícitas as provas obtidas a partir de colaboração premiada não levada a termo. Buscou-se trazer maior segurança jurídica ao indivíduo que busca o órgão de persecução para a propositura do acordo, reforçando a compreensão de que as provas devem ser inutilizadas, para quaisquer fins, nos casos de não celebração. Em outros termos, os casos de lavagem de provas utilizando o procedimento de colaboração premiada, em decorrência da afronta ao dispositivo, bem como em razão da quebra da cadeia de custódia, acabariam por levar à ilicitude de utilização das informações no caso de não celebração do acordo $^{70}$.

Nas disposições processuais relativas à ilicitude das provas, contudo, deve-se ressaltar que não será declarada a nulidade da prova mesmo que obtida ilicitamente -, quando (i) não evidenciado o nexo de causalidade entre a conduta ilegal ou inconstitucional e a prova obtida ou (ii) quando a prova derivada da ilícita puder ser obtida por uma fonte independente da prova ilícita.

Com isso, em que pese a lei tenha se esforçado para diminuir a insegurança jurídica ao indivíduo em colaboração com o dispositivo, identificam-se duas situações em que o fenômeno da lavagem de provas na colaboração premiada gera diferentes efeitos sobre a cadeia de custódia e licitude das provas.

A primeira situação é aquela em que a autoridade passa a utilizar as informações obtidas após a negativa do acordo ${ }^{71}$. Neste caso, as novas provas "lavadas" - obtidas a partir da negativa do acordo - estarão eivadas de nulidade, com base na regra expressa do $\S 6 .^{\circ}$ do art. $3^{\circ}-\mathrm{B}$ da Lei n. ${ }^{\circ}$ 12.850/2013, em leitura conjunta com o art. 157 do CPP.

Com o fim de evitar a lavagem nestes casos e melhor identificar a cadeia de custódia, tal trabalho pode restar facilitado caso a defesa tome cautelas como: (i) a inserção de cláusulas ou safeguards diretamente

70 Neste sentido, ver MENDONÇA, Andrey Borges de. Aspectos controvertidos da negociação da colaboração premiada na experiência brasileira. In: AMBOS, Kai; ZILLI, Marcos; MENDES, Paulo de Sousa (Org.). Colaboração Premiada: perspectiva de direito comparado. São Paulo: Tirant lo Blanch, 2020. p. 45-47.

71 Relembra-se a segunda possibilidade de desfecho do caso hipotético apresentado na seção 3, acima. 
no pré-acordo ou no acordo, discriminando as provas que não poderão ser utilizadas em seu desfavor; (ii) a documentação dos elementos e informações concedidas; bem como (iii) certificando a devolução dos documentos e informações prestadas ${ }^{72}$.

No entanto, a verificação neste caso é complexa, sendo hercúleo o trabalho defensivo para identificar a eventual lavagem realizada, seja em razão do sigilo imposto às investigações em curso, seja pela ausência do dever de disclosure por parte da acusação. Implica este caso uma real situação em que a cadeia de custódia dos novos elementos poderá estar obscura ou dissimulada, entretanto, sem que possa ser efetivamente identificada.

Já a segunda situação consiste no caso em que a autoridade use as informações durante as negociações e só então passe a declinar o acordo. Neste caso, o fenômeno da lavagem se torna ainda mais complexo.

Relembra-se que a palavra do colaborador não é suficiente, por si só, para embasar uma sentença condenatória, além de não autorizar o juízo de admissibilidade positivo da acusação $0^{73}$. Aliás, muitas das informações lançadas pelos colaboradores não vêm acompanhadas de material probatório, seja em razão do dificultado acesso a materiais apreendidos, seja pelo fato de estarem fundadas na própria inaptidão do colaborador para a produção probatória.

Esse déficit implica, necessariamente, a diligência persecutória do órgão acusador ainda durante a negociação. Em outros termos, a colaboração poderá ensejar novas diligências e produção de informações e elementos de prova, algo amparado pelo $\S 4 .^{\circ}$ do art. $3 .^{\circ}-\mathrm{B}$ da Lei ${ }^{\circ}{ }^{\circ}$ $12.850 / 2013^{74}$. Neste caso, quando as diligências surgem durante as

72 MENDONÇA, op. cit., p. 45-47.

73 BRASIL. Supremo Tribunal Federal. Inquérito ${ }^{\circ}$ 3.944, Relator Min. Dias Toffoli, $2^{\text {a }}$ Turma, Brasília, 6 abr. 2018. Disponível em: <https://bit.ly/33ssYPv>. Acesso em 10 fev. 2020. No mesmo sentido: BOTTINI, Pierpaolo Cruz. A palavra do colaborador não é suficiente para o recebimento da denúncia. Conjur, 04 de junho de 2018. Disponível em: <https://bit.ly/2xSP0PP $>$. Acesso em 12 mar. 2020.

74 Ver MENDONÇA, Andrey Borges de. Aspectos controvertidos da negociação da colaboração premiada na experiência brasileira. In: AMBOS, Kai; ZILLI, Marcos; MENDES, Paulo de Sousa (Org.). Colaboração Premiada: perspectiva de direito comparado. São Paulo: Tirant lo Blanch, 2020. p. 31. 
negociações, embora exista eventual lavagem de provas - ainda que premeditada e em claro desfavor do pretenso colaborador - , parece inexistir afronta direta ao $\S 6 .^{\circ}$ do art. $3 .^{\circ}-\mathrm{B}$ da Lei 12.850/2013 ou necessária violação da cadeia de custódia da prova, dada a autorização e o incentivo legal de investigação concomitante.

Pelo exposto, observa-se a possibilidade de existir lavagem de provas sem que dela resulte, necessariamente, nulidade ou ilicitude das novas provas obtidas. E, mesmo havendo a nulidade, resta praticamente impossível sua demonstração em casos concretos ${ }^{75}$.

Nota-se, portanto, que a lavagem de provas tem o condão de criar situações notavelmente desfavoráveis e de grande insegurança jurídica aos pretensos colaboradores, como (provavelmente) ocorrido no MS/SP n. ${ }^{\circ} 35.693$ e, seguramente ocorrido na terceira opção do caso hipotético proposto na seção 3 , acima. Diante da problemática exposta, é que se buscam possíveis soluções para o fenômeno.

\section{Possíveis soluções para a lavagem de PROVAs: O USO DE LIÇÕES TRAZIDAS PELO PROGRAMA DE LENIÊNCIA DO CADE}

Pode-se dizer que o acordo de leniência é, sistematicamente, equiparável à colaboração premiada ${ }^{76}$, ao menos para os fins deste estudo. Desta forma, muito do que se discorreu acerca da lavagem de provas na colaboração premiada pode ser, mutatis mutandis, aplicável à experiência negocial dos acordos de leniências. Tratando-se o programa de leniência do CADE a mais antiga iniciativa brasileira (institucionalizada) de justiça negocial, este constitui importante parâmetro concreto para estudo, devido às suas duas décadas de amadurecimento, motivo pelo qual toma-se o modelo do CADE por base para análise.

Inicialmente, deve-se destacar que a instituição de programas de leniência teve início na autoridade antitruste norte-americana, o

75 Vale a ressalva de que, se tratando de fenômeno complexo, não se objetiva uma resposta genérica e objetiva para todos os casos. Deve-se necessariamente analisar e averiguar eventual ilicitude a cada caso.

${ }^{76}$ MENDRONI, Marcelo Batlouni. Lavagem de Dinheiro. 4.ed. São Paulo: Atlas, 2018. p. 94. 
Department of Justice (DOJ), que, em 1978, instituiu o primeiro programa de leniência no mundo. Em que pese o projeto inicial não ter trazido muitos frutos - até meados da década de 1990, a média era inferior a um acordo por ano e nenhum dos acordos auxiliou na descoberta de cartéis -, o novo modelo acabou por ser redesenhado em 1993, trazendo maiores possibilidades e aumentando a segurança jurídica para as entidades privadas ${ }^{77}$. Com as alterações no procedimento, diversos cartéis foram descobertos, devidamente processados e condenados. Enormes quantidades de multas foram aplicadas ${ }^{78}$, resultando em diversas condenações criminais que, por sua vez, levaram grandes executivos a cumprir penas de prisão ${ }^{79}$.

Diante dos resultados positivos da experiência americana, países como Austrália, Canadá, França, Alemanha, Nova Zelândia, Reino Unido, e Suécia, bem como o bloco denominado União Europeia, introduziram programas análogos em suas agências ${ }^{80}$. Seguindo a denominada "leniency revolution" 81 o Brasil também instituiu o seu próprio programa em $2000^{82}$, com o primeiro acordo sendo celebrado em 2003, e, a partir deste, outros 101 tendo sido celebrados até o ano de $2020^{83}$.

Em estudo acerca do tema, Marcos Paulo Verissimo indica que os programas de leniência - em especial dos EUA e da União Europeia ${ }^{84}$ — só

77 HAMMOND, Scott d. The evolution of criminal antitrust enforcement over the last two decades. Disponível em: <https://bit.ly/2U1mfJa >. Acesso em 10 de fev. 2020.

78 Apenas na década de 1990 estima-se que foram aplicados ao todo 1,6 bilhões de dólares em multas, superando os 188 milhões de dólares na década de 1980, e 48 milhões da década de 1970. Ibid., p. 6.

79 Segundo os dados do DOJ, 37 condenações por ano durante a década de 1990, com o aumento significativo da média durante a década de 2000, com a média chegando a 62 condenações por ano. Ibid., p. 9.

80 SPAGNOLO, Giancarlo. Leniency and Whistleblowers in Antitrust. Disponível em:<https://bit.ly/33vlHyw>. Acesso em 10 fev. 2020.

81 Ibid., p. 7.

82 MARTINEZ, Ana Paula. Repressão a Cartéis: interface entre direito administrativo e direito penal. Singular: São Paulo, 2013. p. 258.

83 CADE. Estatísticas do Programa de Leniência do Cade. Disponível em: <https://bit.ly/2x69Lag>. Acesso em 02. fev. 2020.

84 Cf. PRADO FILHO, José Inácio F. de Almeida; Bruna Sellin (Org.). Acordos e políticas de leniência: contribuição para o diálogo e a harmonização. São Paulo: Singular, 2020. p. 79-99. 
passaram a obter tal sucesso quando passaram a conferir aos colaboradores (i) transparência, (ii) segurança jurídica, (iii) certeza do resultado do processo e (iv) critérios objetivos de concessão da leniência ${ }^{85}$. Estas lições foram especialmente compreendidas na autoridade antitruste brasileira, sendo várias as medidas tomadas em favor de desenvolver, propriamente, um programa de leniência.

Resgatando a problemática do trabalho, verifica-se que são duas as principais características que tornam a lavagem de provas um fenômeno latente durante as negociações dos acordos de colaboração premiada: (i) a autoridade que negocia o acordo é a mesma que investiga e processa criminalmente, como já mencionado, e (ii) o fato de inexistir clareza acerca da gestão da prova, que também se reflete na ausência de um "programa" — ou diretriz - claro de colaboração premiada nos órgãos de acusação. Para estes problemas, que têm o potencial de gerar grande insegurança jurídica aos pretensos colaboradores, é que o programa de leniência do CADE possui interessantes soluções, as quais se pretende explorar.

No CADE, embora a autoridade responsável pela investigação, negociação e assinatura de acordos de leniência seja o Superintendente-Geral ${ }^{86}$, a experiência e a consolidação do programa ao longo de duas décadas resultaram na disposição separada entre setores investigativos e negociantes. Esta cisão tem como objetivo resguardar as diferentes atribuições da superintendência e promover a adequada gestão probatória e de informações sensíveis compartilhadas pelo leniente ${ }^{87}$, criando uma "chinese wall" dentro do órgão. Isto é, existe uma unidade especialmente

85 VERISSIMO, Marcos Paulo. Acordos de leniência: a experiência nacional e internacional de combate a cartéis e sua transposição para o combate à corrupção no Brasil. In: AMBOS, Kai; ZILLI, Marcos; MENDES, Paulo de Sousa. (Org.). Corrupção: ensaios sobre a operação lava jato. São Paulo: Marical Pons, 2019. p. 143.

Cf. ATHAYDE, Amanda. Manual dos Acordos de Leniência no Brasil: teoria e prática - CADE, BC, CVM, CGU, AGU, TCU, MP. Belo Horizonte: Fórum, 2019. p. 77.

87 Destaca-se que a Superintendência-Geral (SG) foi estruturada a partir da divisão em duas Superintendências Adjuntas: com a Superintendência-Geral Adjunta 1 (SGA-1) sendo responsável por controle de cartéis e a Superintendência-Geral Adjunta 2 (SGA-2) responsável por Atos de Concentração e Unilaterais, cada uma contando com suas próprias coordenações gerais para triagem e correta instrução, investigação e tramitação dos casos. Entretanto, 
dedicada à negociação dos acordos de leniência que não abarca os servidores públicos responsáveis por conduzir as investigações do órgão $0^{88}$. Desta forma, não se compromete a capacidade defensiva do proponente frente ao próprio CADE - que confessa a prática anticoncorrencial - , no caso de recusa no acordo, bem como diante outras esferas, sejam administrativas ou judiciais.

De todo modo, em que pese exista cognição por parte do Superintendente-Geral, a correta gestão de provas e a segurança do não compartilhamento de informações sensíveis são temas centrais dentro do programa de leniência do CADE. Essa questão como um todo tomou tamanha importância para o programa que foi editada a Resolução n. ${ }^{\circ}$ 21/2018 ${ }^{89}$ pelo Tribunal do CADE. Tais disposições foram elaboradas buscando, sempre em respeito à Lei de Acesso à Informação, resguardar documentos sensíveis do domínio público ${ }^{90}$.

o departamento de acordos de leniência não compõe a estrutura das SGAs, ficando sob o manto do gabinete da SG, funcionando de maneira autônoma.

MARTINEZ, Ana Paula. Parâmetros de negociação de acordo de leniência com o MPF à luz da experiência do CADE. In: BOTTINI, Pierpaolo Cruz; MOURA, Maria Thereza de Assis (Coord.). Colaboração Premiada. São Paulo: RT, 2017. p. 37.

89 CADE. Resolução $n^{\circ} 21$ de 12 de setembro de 2018. Disciplina os procedimentos previstos nos arts. 47, 49, 85 e 86 da Lei n ${ }^{\circ} 12.529$, de 2011, relativos à articulação entre persecução pública e privada às infrações contra a ordem econômica no Brasil. Regulamenta os procedimentos de acesso aos documentos e às informações constantes dos Processos Administrativos para Imposição de Sanções Administrativas por Infrações à Ordem Econômica, inclusive os oriundos de Acordo de Leniência, de Termo de Compromisso de Cessação (TCC) e de ações judiciais de busca e apreensão, além de fomentar as Ações Civis de Reparação por Danos Concorrenciais (ACRDC). Conselho Administrativo de Defesa Econômica. 12, set 2018. Disponível em: <https://bit. ly/3a5giAo>. Acesso em 10 mar. 2020.

90 Estão previstos no art. 2. ${ }^{\circ}$ da Resolução: (a) o histórico de Conduta e seus aditivos, elaborados pela Superintendência-Geral do Cade com base em documentos e informações de caráter auto-acusatório submetidos voluntariamente no âmbito da negociação de Acordo de Leniência e TCC, em razão do risco à condução de negociações (art. 23, II, da Lei $\mathrm{n}^{0} 12.527 / 2011$ ), às atividades de inteligência (art. 23, VIII, da Lei $n^{0} 12.527 / 2011$ ), e/ou à efetividade dos Programas de Leniência e de TCC, em razão do risco à condução de negociações (art. 23, II, da Lei $\mathrm{n}^{0} 12.527 / 2011$ ), às atividades de inteligência (art. 23, VIII, da Lei n ${ }^{\circ} 12.527 / 2011$ ), e/ou à efetividade dos Programas de 
Essas simples diligências do CADE seguem as antigas lições dos programas de leniência americano e europeu, que precisaram trabalhar e realizar reformas a fim de estabelecer e pacificar os pontos de insegurança jurídica. Nesse sentido, a Resolução busca pacificar e esclarecer que, a depender da forma pela qual o acordo é negociado e a forma de tratamento e gestão da prova, a autoridade negociante pode auxiliar e promover segurança jurídica a seus colaboradores, recebendo em troca um auxílio do envolvido nas suas capacidades investigativas. Isso, naturalmente, fortalece e promove o institucional programa de leniência da autoridade.

Conforme o disposto, nota-se que o programa de leniência do CADE já apresenta sinais de amadurecimento, com o incremento de adeptos à sua política premial. Embora muitas das questões relacionadas à gestão da prova e do sigilo dentro do órgão já estejam pacificadas, a manutenção da segurança jurídica no âmbito do programa de leniência do CADE também passa pela via da promoção da "advocacia da concorrência" ${ }^{1}$ - i.e., a contínua difusão dos valores da concorrência que, no caso, também englobam a conscientização da lesividade de ações que busquem a devassa probatória e de informações sensíveis como fatores de desestímulo e contrários à política empregada pelo órgão.

Sugere-se que estas três medidas adotadas no âmbito dos acordos de leniência do CASO sejam espelhadas em matéria criminal, incluindo eventuais reestruturações internas e até mesmo políticas - em sentindo amplo - dentro dos órgãos negociantes, especialmente o Ministério Público. Explica-se.

Leniência e de TCC do Cade; e (b) outros documentos e/ou informações de caráter sigiloso.

91 O termo advém do inglês "competition advocacy" e, segundo Eduardo Jordão, é utilizado para se referir às ações empreendidas (em geral) pelas entidades da defesa da concorrência para divulgar a filosofia concorrencial. Tem como objetivo difundir na sociedade civil os valores relacionados à competitividade e persuadir entidades governamentais a atuar de modo amigável aos princípios da concorrência e a evitar medidas que lhes sejam desnecessariamente lesivas. JORDÃO, Eduardo Ferreira. A advocacia da concorrência como estratégia para redução do impacto anticompetitivo da regulação estatal. Revista Brasileira de Direito Público, v. 24. 2009. p. 127-154. O termo é empregado, atualmente, na denominação dada à Secretaria de Promoção da Produtividade e Advocacia da Concorrência - Seprac, vinculada ao Ministério da Economia. 
Para a primeira problemática - de unicidade entre autoridade negociante ${ }^{92} \mathrm{e}$ autoridade investigativa-persecutória - a exemplo do que faz o CADE, poderia ser bastante produtivo e resultar em maior segurança jurídica às defesas em colaboração, se houvesse um órgão central de colaboração nos Ministérios Públicos. Tais autoridades centrais poderiam negociar - sempre em auxílio do promotor natural - evitando que as informações sensíveis obtidas na negociação ficassem sob a custódia única do membro natural, antes da homologação do acordo, desestimulando a eventual prática de lavagem de provas. Tal medida, aliada à identificação de elementos, provas, datas e cláusulas no pré-acordo garantiriam a cadeia de custódia da prova e maior higidez no procedimento. Desse modo, promover-se-ia a institucionalidade na tratativa do acordo, isto é, a relação entre indivíduo e Estado - em detrimento de uma eventual e (indesejada) personalização entre o membro responsável com as partes.

Neste ponto, interessante trazer uma segunda lição do CADE: existe um programa claro de leniência, com diretrizes, transparência e garantias $^{93}$. A colaboração premiada, enquanto instituto, também poderia assim ser tratada dentro do Ministério Público ou, ao menos, efetivamente regulamentada. Isto é, seria de grande utilidade a preocupação com um tratamento uniforme, contando com guias, modelos, diretrizes e normas de boas práticas dentro das negociações dos acordos, somado a programas como o de proteção a testemunhas. Não obstante, seria de interesse criar um mecanismo de revisão e pacificação de entendimento acerca do tema, tal qual existente nas Câmaras de Coordenação e Revisão do MPF, replicado aos demais órgãos negociantes. Em suma, efetivamente, algo pensado de modo a constituir um ambiente institucional de justiça negocial.

Por fim, e como última lição trazida da experiência junto ao CADE: ao lado das medidas já apontadas, deve-se promover nos órgãos

92 Ressalva-se o entendimento de que, na justiça penal negocial, deve o Ministério Público atuar mais como parte em negociação e menos como autoridade, que se coloca frente ao imputado para a concessão de alguma espécie de benefício. Nesse sentido, ver LUCCHESI, Guilherme Brenner; ARNS DE OLIVEIRA, Marlus H. Sobre a discricionariedade do Ministério Público no ANPP e o seu controle jurisdicional: uma proposta pela legalidade. Boletim IBCCRIM, São Paulo, ano 29, n. 344, p. 26-28, jul. 2021.

93 Cf. CADE. Programa de Leniência. Disponível em: <https://bit.ly/3jRiN0J>. Acesso em 06. set. 2021. 
negociantes da colaboração premiada uma filosofia equivalente à da “advocacia da concorrência”, existente nos órgãos negociantes do CADE. Destacam-se entre os pilares que promoveram o sucesso nos programas de leniência: o reforço de boas práticas, a institucionalização, a correta gestão de provas e a conscientização das partes acerca dos benefícios da negociação. Semelhante filosofia no âmbito da colaboração premiada poderá contribuir não apenas para a promoção de segurança jurídica e maior confiabilidade e transparência nos órgãos de acusação, como, consequentemente, em mais e melhores acordos celebrados.

\section{Conclusões}

A colaboração premiada é um instituto que se mostra indispensável ao desbaratamento da nova criminalidade organizada e que tem demonstrado resultados extremamente positivos para a sociedade. Sua natureza jurídica, como um fenômeno complexo, implica a leitura de que é um meio de obtenção de prova, um negócio jurídico processual e um mecanismo legítimo de defesa do imputado.

Passou-se à discussão acerca do fenômeno da lavagem de provas, conceituando-o como a ocultação ou dissimulação da origem da informação - de regra inutilizável no processo - como fonte de novos meios de prova. Identificou-se que o momento propício para a ocorrência da lavagem é a fase de negociação de um acordo de colaboração premiada.

A partir de um caso hipotético, vislumbraram-se ao menos três medidas durante as negociações a serem tomadas pela autoridade negociante (MP), as quais podem levar a diferentes situações jurídicas, dentre elas, a ocorrência da lavagem de provas.

A primeira delas e mais simples, é quando o órgão acusador apenas encerra a negociação e não utiliza as provas apresentadas, razão pela qual não há qualquer movimento de lavagem de provas ou de ilicitude por parte da acusação, apenas se constituindo a aquisição de elementos informativos por parte da autoridade negociante - o que é natural, a partir da entrega e do conhecimento de materiais.

A segunda ocorre quando a acusação encerra as tratativas e se utiliza das informações que obteve confidencialmente, ainda que sem acesso aos materiais. Neste caso, concluiu-se que se configura uma 
autêntica lavagem de provas, e com uma consequente quebra na cadeia de custódia, de modo que as informações obtidas por este meio são ilícitas.

E, por fim, em uma terceira hipótese, quando a autoridade, durante as negociações, utiliza-se dos materiais apresentados e obtém elementos equivalentes de forma cruzada ou de maneira independente, e, somente ao final das investigações e averiguações acaba por declinar do acordo de colaboração. Nesta última hipótese, concluiu-se que há a lavagem de provas, no entanto, não é uma situação em que há nulidade ou ilegalidade das provas obtidas a partir dos documentos entregues pelo colaborador, uma vez que a colaboração admite a investigação complementar nesta fase nos termos dos $\S 4 .^{\circ}$ do art. $3 .^{\circ}-\mathrm{B}$ da Lei n. ${ }^{\circ} 12.850$ de 2013.

Assim, diante dessa última possibilidade, é que se passou a discutir uma possível forma de combate a esta conduta por parte da acusação, destacando a importância de assegurar ao colaborador que sua pretensa colaboração, ainda que na fase de negociação, seja efetivamente levada em seu favor. Neste contexto, utilizou-se como modelo o programa de leniência instituído pelo CADE, aproveitando-se de suas características e diligências para a correta gestão da prova, de forma a evitar devassas e investigações baseadas única e exclusivamente na quebra da boa-fé negocial, especialmente destacando-se a divisão interna entre o departamento de leniência e os de investigação e apuração de infrações.

Seguindo as lições do programa, como forma de evitar ou minimizar os nefastos efeitos da lavagem de provas, sugere-se o uso de três lições do programa de leniência antitruste a serem aplicados na colaboração premiada: (i) criação de uma autoridade central responsável pela negociação de acordos de colaboração premiada, em auxílio ao promotor natural; (ii) criação de um "programa" de colaboração premiada ou, ao menos, sua regulamentação em âmbito interno; e (iii) promoção e difusão dos valores e boas práticas dentro das negociações e acordos de colaboração premiada, tal qual realizado no antitruste com a "advocacia da concorrência".

\section{REFERÊNCIAS}

AMBOS, Kai; ZILLI, Marcos; MENDES, Paulo de Sousa (Org.). Colaboração Premiada: perspectiva de direito comparado. São Paulo: Tirant lo Blanch, 2020. 
AMBOS, Kai; ZILLI, Marcos; MENDES, Paulo de Sousa. (Org.). Corrupção: ensaios sobre a operação lava jato. São Paulo: Marcial Pons, 2019.

ARAS, Vladmir. "Enganei o juiz e me dei bem”. Disponível em: <https://bit.ly/ 38wGbtN>. Acesso em 01 set. 2021.

ATHAYDE, Amanda. Manual dos Acordos de Leniência no Brasil: teoria e prática CADE, BC, CVM, CGU, AGU, TCU, MP. Belo Horizonte: Fórum, 2019.

BADARÓ, Gustavo Henrique. Processo Penal. 2.ed. São Paulo: RT, 2013.

BITTAR, Walter B. Delação premiada: direito, doutrina e jurisprudência. 3.ed. São Paulo: Tirant Lo Blanch, 2020.

BOTTINI, Pierpaolo Cruz. A palavra do colaborador não é suficiente para o recebimento da denúncia. Conjur, 04 de junho de 2018. Disponível em: <https:// bit.ly/2xSP0PP>. Acesso em 12 mar. 2020.

BOTTINI, Pierpaolo Cruz; MOURA, Maria Thereza de Assis (Coord.). Colaboração Premiada. São Paulo: RT, 2017.

CALLEGARI, André Luís; LINHARES, Raul Marques. Colaboração Premiada: lições práticas e teóricas: de acordo com a jurisprudência do Supremo Tribunal Federal. 2.ed. Porto Alegre: Livraria do Advogado, 2019.

CORDEIRO, Nefi. Colaboração Premiada: caracteres, limites e controles. Rio de Janeiro: Forense, 2020.

COSTA, Leonardo Dantas. Delação Premiada. A atuação do Estado e a relevância da voluntariedade do colaborador com a justiça. Curitiba: Juruá, 2017.

DORAN, Robert A. Exploring the links in the chain of custody. In: Nebraska Association for Property and Evidence (NAPE) Annual Training Conference, 2005. Disponível em: <https://bit.ly/2xHKl2P>. Acesso em em 10 mar. 2020.

DRESSLER, Joshua; THOMAS III, George C. Criminal Procedure: prosecuting crime. 6.ed. Minnesota: West Academic Publishing, 2017.

ENCLA. Manual de Colaboração Premiada. Estratégia Nacional de Combate a Corrupção e à Lavagem de Dinheiro. Jan. 2014. Disponível em: <https://bit. ly/3a1bQ5X>. Acesso em 19 fev. 2020.

FERREIRA, Marco Aurélio Gonçalves. A ausência do crime de perjúrio no sistema jurídico brasileiro. Revista da SJRJ, Rio de Janeiro, v. 17, n. 29, dez. 2010.

FIGUEIREDO DIAS, Jorge de. Direito processual penal. Coimbra: Coimbra, 1974. p. 126-127.

FONSECA, Cibele Benevides Guedes. Colaboração premiada. Bel Horizonte: Del Rey, 2017. 
GAVRONSKI, Alexandre Amaral; MENDONÇA, Andrey Borges de. Manual do Procurador da República: Teoria e Prática. 3.ed. Salvador: JusPodivm, 2017.

GOMES, Luiz Flávio; SILVA, Marcelo R. Organizações Criminosas e técnicas especiais de investigação. Salvador: JusPodivm, 2015.

LUCCHESI, Guilherme Brenner; ARNS DE OLIVEIRA, Marlus H. Sobre a discricionariedade do Ministério Público no ANPP e o seu controle jurisdicional: uma proposta pela legalidade. Boletim IBCCRIM, São Paulo, ano 29, n. 344, p. 26-28, jul. 2021.

PEREIRA, Frederico Valdez. Eficácia da colaboração premiada e controle judicial. Homologação e sentenciamento. In: GEBRAN NETO, João Pedro (Org.). Colaboração premiada: perspectivas teóricas e práticas. Porto Alegre: Verbo Jurídico, 2020.

PEREIRA, Gustavo Alberine. Investigação defensiva no Brasil: limites e possibilidades no processo penal brasileiro. Dissertação (Mestrado) - Programa de Pós-Graduação em Direito, PUCRS. Porto Alegre, 2019. Disponível em: < https:// bit.ly/38ynA0s>. Acesso em 01. set. 2021.

HAMMOND, Scott d. The evolution of criminal antitrust enforcement over the last two decades. Disponível em: <https://bit.ly/2U1mfJa>. Acesso em 10 de fev. 2020.

JORDÃO, Eduardo Ferreira. A advocacia da concorrência como estratégia para redução do impacto anticompetitivo da regulação estatal. Revista Brasileira de Direito Público, v. 24. 2009.

LOPES JR., Aury. Fundamentos do Processo Penal: introdução crítica. São Paulo: Saraiva, 2015.

MACHADO, André Augusto Mendes. Investigação Criminal Defensiva. São Paulo: Revista dos Tribunais, 2010.

MARTINEZ, Ana Paula. Repressão a Cartéis: interface entre direito administrativo e direito penal. Singular: São Paulo, 2013. p. 258.

MENDRONI, Marcelo Blatouni. Lavagem de Dinheiro. 4.ed. São Paulo: Atlas, 2018. p. 94.

MORAES, Rafael Francisco Marcondes de; PIMENTEL JÚNIOR, Jaime. Polícia Judiciária e a atuação da defesa na investigação criminal. 2.ed. Salvador: Juspodivm, 2018.

MORAIS DA ROSA, Alexandre. Para entender a delação premiada pela teoria dos jogos: táticas e estratégias do negócio jurídico. Florianópolis: Emodara, 2018. 
OLIVEIRA, Marlus Heriberto Arns de. A colaboração premiada como legítimo instrumento de defesa na seara do Direito Penal Econômico. 2016. Tese (Doutorado em Direito Econômico e Socioambiental) - Escola de Direito da Pontifícia Universidade Católica do Paraná. Curitiba, 2016.

PACELLI, Eugênio; CORDEIRO, Nefi; REIS JÚNIOR, Sebastião dos (Coord). Direito penal e processual penal contemporâneos. São Paulo: Altas, 2019.

PEREIRA, Frederico V. Delação Premiada: legitimidade e procedimento. Curitiba: Juruá, 2019.

POMPEU, Ana. MP não é obrigado a formalizar acordo de delação, decide $2^{\mathrm{a}}$ Turma do STF. Consultor Jurídico. 28 mai. 2019. Disponível em: <https://bit.ly/2Ujlb2k>. Acesso em 28 de fevereiro de 2020.

PRADO FILHO, José Inácio F. de Almeida; Bruna Sellin (Org.). Acordos e políticas de leniência: contribuição para o diálogo e a harmonização. São Paulo: Singular, 2020.

PRADO, Geraldo. Prova penal e sistema de controles epistêmicos: a quebra da cadeia de custódia das provas obtidas por métodos ocultos. São Paulo: Marcial Pons, 2014.

SANTOS, Marcos Paulo Dutra. Colaboração (delação) premiada. Salvador: Juspodivm, 2016.

SILVA, Eduardo Araújo da. Organizações criminosas. Aspectos penais e processuais da Lei 12.850/2013. 2.ed. São Paulo: Atlas, 2015.

SILVA, Franklyn Roger Alves. Investigação Criminal Direta pela Defesa. Salvador: Juspodivm, 2019.

SPAGNOLO, Giancarlo. Leniency and Whistleblowers in Antitrust. Disponível em:<https://bit.ly/33vlHyw>. Acesso em 10 fev. 2020.

TROTT, Stephen S. Uso de um criminoso como testemunha: um problema especial. Tradução de Sérgio Fernando Moro. Revista CEJ, Brasília, Ano XI, n. 37.

VASCONCELLOS, Vinicius Gomes de. Colaboração Premiada no Processo Penal. 2.ed. São Paulo: RT, 2018.

YARSHEL, Flávio Luiz; ZANOIDE DE MORAES, Maurício (orgs.). Estudos em homenagem à Professora Ada Pellegrini Grinover. São Paulo: DPJ, 2005.

WUNDERLICH, Alexandre. "Sanção premial diferenciada" após o pacote "anticrime”. ConJur, 9 jan. 2020. Disponível em: <https://bit.ly/3v8QBKs>. Acesso em 9 mar. 2021. 


\section{Additional information and author's declarations (scientific integrity)}

Declaração de conflito de interesses (conflict of interest declaration): the authors confirm there are no conflicts of interest in conducting this research and writing this article.

Declaração de autoria e especificação das contribuições (declaration of authorship): all and only researchers who comply the authorship requirements of this article are listed as authors; all coauthors are fully responsible for this work in its entirety.

- Guilherme Brenner Lucchesi: methodology, writing validation, review and editing, final version approval.

- Lucas Gandolfi Vida: conceptualization, data curation, investigation, writing - original draft, final version approval.

Declaração de ineditismo e originalidade (declaration of originality): the authors assure that the text here published has not been previously published in any other resource and that future republication will only take place with the express indication of the reference of this original publication; they also attest that there is no third-party plagiarism or self-plagiarism.

\section{Dados do processo editorial}

(http://www.ibraspp.com.br/revista/index.php/RBDPP/about/editorialPolicies)

- Recebido em: 24/03/2021

- Controle preliminar e verificação de plágio: 04/04/2021

- Avaliação 1: 22/04/2021

- Avaliação 2: 06/05/2021

- Decisão editorial preliminar: 17/08/2021

- Retorno rodada de correções 1: 15/09/2021

- Decisão editorial preliminar 2: 01/10/2021

- Retorno rodada de correções 2: 01/10/2021

- Decisão editorial final: 01/10/2021

\section{Equipe editorial envolvida}

- Editor-chefe: 1 (VGV)

- Editor-assistente: 1 (FDL)

- Revisores: 2 


\section{HOW TO CITE (ABNT BRAZIL):}

LUCCHESI, Guilherme B.; VIDA, Lucas G. Perspectivas quanto à lavagem de provas na colaboração premiada: proposta para controle de abuso processual. Revista Brasileira de Direito Processual Penal, vol. 7, n. 3, p. 2203-2243, set./dez. 2021. https://doi.org/10.22197/rbdpp.v7i3.542

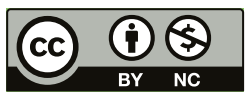

Esta obra está licenciada com uma Licença Creative Commons Atribuição-NãoComercial 4.0 Internacional. 